International Journal of Economics, Business and Accounting Research (IJEBAR)

Peer Reviewed - International Journal

Vol-, Issue-, 2020 (IJEBAR)

E-ISSN: 2614-1280 P-ISSN 2622-4771

https://jurnal.stie-aas.ac.id/index.php/IJEBAR

\title{
THE INFLUENCE OF ORGANIZATIONAL CLIMATE AND ORGANIZATIONAL COMMITMENT TO TURNOVER INTENSION OF EMPLOYEES OF PT SALAH SATU BRANCH OF BANK BUMN
}

\author{
Nur haris ependi ${ }^{1}$ D. purnomo ${ }^{2}$ Siswandi $^{3}$ \\ Politeknik LP3i Jakarta \\ Email:hrsbox@gmail.com
}

\begin{abstract}
The purpose of this study is to measure the impact of organizational commitment organizational climate on employee turnover intentions of one state-owned bank in Jakarta. The method used in this study is to use a quantitative descriptive analysis involving employees at one of the state-owned banks using random sampling technique with proportional random sampling as many as 78 respondents. The data collection technique used is the questionnaire method which is supported by the documentation method with multiple linear regression analysis techniques. The results of the study can be indicated (1) There is a significant positive effect between organizational climate on employee turnover intentions where the negative value is $-0,177$ and the results of the $t$ test are $-1,737$ which means $t$ arithmetic is less than $t$ table ($1.737<1.995)$. (2) There is a significant positive effect between organizational culture on turnover intentions with a negative value of -0.424 and $t$-test results is 4.150, which means $t$ arithmetic is less than t table $(-4,150<1,995)(3)$ There is a significant positive influence between organizational climate and organizational culture on employee turnover in which the value of $\mathrm{f}$ arithmetic is greater than $\mathrm{f}$ table that is $10,567>3.11$.
\end{abstract}

Keywords: $\quad$ Organizational Climate Organizational commitment and turnover intentions

\section{Introduction}

The banking industry has so far been considered a strategic industry and has an important contribution to the development of a country's economy, including Indonesia. From the business side, banking is also an industry that promises huge profits. Especially in Indonesia, it is a strategic and potential market for the banking industry due to its large population and economic conditions that show positive growth. Each bank is competing to strengthen its market share in order to obtain greater profits. Furthermore, foreign banks are also aggressively expanding in Indonesia which adds to the tighter banking industry

At present there are still shortcomings, especially in the staffing structure. There are some of the employees who want to move to another company for various reasons. Employee turnover is a phenomenon that often occurs in the banking industry. Harnoto argues in his book (Nasution, 2009: 121) that Turnover Intention is the level of intensity of self-desire to leave the company. Turnover can also be interpreted as the movement of workers out of the organization. Turnover leads to the final reality faced by an organization in the form of the number of employees who leave the organization in a certain period, while the desire of employees to move (turnover intention) refers to the results of individual evaluations regarding the continuation of relationships with the organization that have not been realized in the action must have left the organization. Turnover can be in the form of resignation, movement out of organizational units, dismissal or death of members of the organization. 
International Journal of Economics, Business and Accounting Research (IJEBAR)

Peer Reviewed - International Journal

Vol-, Issue-, 2020 (IJEBAR)

E-ISSN: 2614-1280 P-ISSN 2622-4771

https://jurnal.stie-aas.ac.id/index.php/IJEBAR

The employee turnover rate (15\%) according to the results of the 2014 PricewaterhouseCoopers (PWC) survey, has become a serious problem for the banking world. Rousseau (1984:32) says that, "the costs or losses of turnover include direct costs related to recruitment activities (including advertising costs, agency fees) and search costs; indirect costs, for example costs associated with training new employees; and productivity losses by the learning process of new employees". Many things were alleged as the cause of an employee's discharge from a job. The current work situation is not in accordance with the desired expectations (the emergence of dissatisfaction at work) or influenced by the views of employees to get alternative work and better satisfaction. Thus, a company is required to be able to retain its employees, such as being able to provide high rewards and understand things that can make employees feel at home to continue working without reducing the company's overall performance.

In line with the above Towers Watson in the 2012 Talent Management and Rewards Survey with a sample of 52 companies in Indonesia, one third of which are banks, found that the company did not understand what factors were considered by employees to remain and not move to other companies. While Woods and Macaulay (1989) explain that high turnover in the banking world raises moral problems for employees who live, and also inflates costs in recruitment, interviews, tests, reference checks, administrative costs for processing new employees, benefits, orientation, and opportunity costs lost because employees have to learn new skills. Problems then arise when banks in Indonesia, including state-owned banks, do not use the same ratio as a formula to increase employee loyalty. Banks have poor statistics in handling human resources (HR). Turnover rates at banks for business functions reach $25 \%$ a year. Only a third of employees are loyal, and nearly half of employees think of getting ready to move to another company for career advancement. Companies in Indonesia, including banks, also stated that most ( 8 out of 10) faced problems in retaining their best employees.

\section{Literature Review . Intention of Turn over}

Ajzen (2006) says that intention is an indication of someone's readiness to show behavior, and this is an antecedent of behavior. Meanwhile Warshaw and Davis (in Landry, 2003) stated that intention is the level at which someone formulates a plan to indicate a specific future goal or not, consciously. Then Warshaw and Davis (in Landry, 2003) also added that the intention involves making a commitment to behavior to show an action or not, where there is an expectation that someone expected to show an action even when the commitment has not been made

Mathis and Jackson (2003) put forward the definition of turnover as a process whereby employees leave the organization and the job position must be replaced by someone else. As with the above Hartono (2002: 92), turnover intention is the level or intensity of the desire to leave the company on their own volition. Reasons for the emergence of a desire to leave his current job, and one of them is to find a better job.

The occurrence of turnover intensity is marked by several things related to employee behavior with the following indicators 1 . Increased absenteeism 2. Starting to be lazy to work 3 . Increased violations of work order 4. Increased protests against superiors and 5. Very different employee behavior than usual.

Robbins (2001) states that a person's withdrawal from an organization (turnover) can be decided voluntarily (voluntary turnover) and involuntary (involuntary turnover). Voluntary turnover or quit is an employee's decision to leave the organization voluntarily due to the factor 
International Journal of Economics, Business and Accounting Research (IJEBAR)

Peer Reviewed - International Journal

Vol-, Issue-, 2020 (IJEBAR)

E-ISSN: 2614-1280 P-ISSN 2622-4771

https://jurnal.stie-aas.ac.id/index.php/IJEBAR

of how attractive the current job is, and the availability of alternative jobs. Conversely, involuntary turnover describes the decision of the employer to terminate the employment relationship and is uncontrollable for employees who experience it (Mobley,).

\section{Organizational Climate}

Robbins and Judge (2013: 550) state that. "Organizational climate refers to the shared perception organizational members have about their organization and work environment". Organizational climate refers to the shared perceptions of organizational members about what they have around the organization and their work environment

While in the opinion of Robert Ivancevich quoted by Michael Armstrong defines the organizational climate as follows, "organizational climate is a set of properties of the work environment. perceived directly or indirectly by the employees, that is assumed to be a major force in influencing employee behavior (Armstrong, 2009: 385) ". Organizational climate is a set of nature of the work environment, felt directly or indirectly by employees, which is assumed to be a major force in influencing employee behavior.

In line with the above (W. R. Plunkett, Attner, \& Allen, 2008: 383) ". Organizational climate is the behavior, attitudes and feelings about the characters that live in the organization. Based on the explanation above, it can be said that the organizational climate is closely related to the individual's perception of the organization's social environment that affects the organization and the behavior of organizational members. Because the concept of organizational climate is based on the personal perceptions of members of the organization, most organizational climate measurements are carried out through questionnaires.

\section{Organizational Commitment}

Employees who have high organizational commitment will feel loyal, obedient, work hard to carry out the tasks given to him and believe in his heart that his organization is the best, so he always wants to stay and do not need to find another organization to work. According to Colquitt, Lepine, \& Wesson (2009: 67) states Organizational Commitment is defined as the desire on the part of an employee to remain a member of the organization withdrawal behavior is a set of actions that employees perform to avoid the work situation. Commitment and withdrawal are negatively related to each other, the more commited an employee is the less likely he or she is to Engange in withdrawal.

Meanwhile, according to Gibson, Ivancevich, Donnelly, and Konopski (2006: 184) states that; Commitment is a sense of identification, loyalty, and involvement expressed by an employee toward the organization or unit of the organization. Commitment to an organization involves three attitudes: (1) a sense of identification with the organization's goals, (2) feeling to involvement in the organizational duities, and (3) a feeling of loyalty for the organization.

Gibson, et al emphasized that commitment is a sense of identification, loyalty, and involvement expressed by employees to the organizational environment or organizational unit. Employee commitment to the organization involves three attitudes: (1) a sense of identification with organizational goals, (2) a feeling of being involved in organizational work, and (3) a feeling of loyalty to the organization). In line with the above Panggabean (2004: Vol.6, 91-92) in his research journal said the desire to change employment is defined as the desire to leave the organization intentionally and consciously. It was also stated that the concept of a desire to change employment could be measured using a questionnaire list which could consist of several questions as had been done by several previous researchers. 
International Journal of Economics, Business and Accounting Research (IJEBAR)

Peer Reviewed - International Journal

Vol-, Issue-, 2020 (IJEBAR)

E-ISSN: 2614-1280 P-ISSN 2622-4771

https://jurnal.stie-aas.ac.id/index.php/IJEBAR

While research conducted by (Steel and Ovalle, 1984: 673) found that the factors of attachment to companies have a negative correlation with turnover intentions. It means that the higher one's attachment to the company, the less will it be to change jobs and switch companies, and vice versa. Employees who have a strong sense of attachment to the company where he works, have and form a feeling of belonging (sense of belonging), a sense of security, efficacy, purpose and meaning in life and a positive self-image. The direct consequence of a sense of attachment to the company is a decrease in the individual's drive to change jobs or leave the company.

\section{Research Framework}

By using the construction of each of the variables described above, then a rational analysis of the relationship between each independent variable is carried out, namely organizational climate and turnover intention with the dependent variable, organizational commitment. The preparation of this thesis is built with the following theoretical framework,

Figure 1.1 Research Constellation

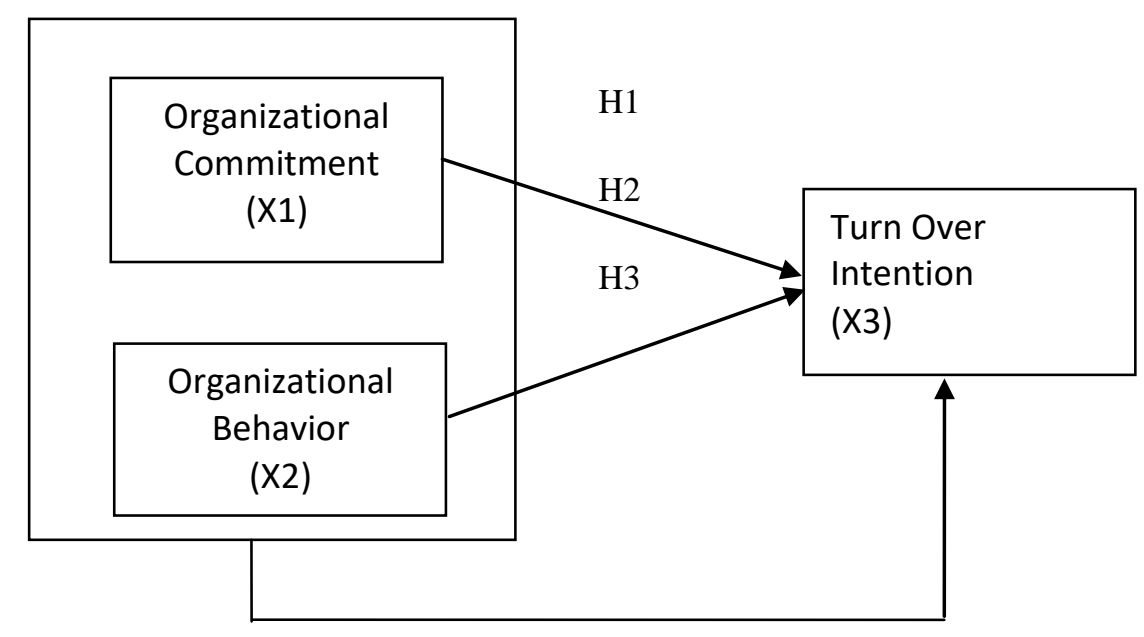

Hypothesis Formulation:

1. H1: There is a significant influence between the organizational climate to the intention of turn over

2. H2: There is a significant influence between organizational culture on intention turn over

3. H3: There is a significant influence of organizational climate on organizational culture to the intention of turn over.

\section{Research Methods}

Types of Research

The method in this research is quantitative descriptive analysis.

\section{Data, Population and Samples}

Location of the study by visiting a direct object in one of the branches of a state-owned bank in Jakarta ... Population and Samples in this study were all employees within the work environment of one of the state-owned banks in Jakarta. Sampling with random sampling technique is proportional random sampling of 78 employees. 
International Journal of Economics, Business and Accounting Research (IJEBAR)

Peer Reviewed - International Journal

Vol-, Issue-, 2020 (IJEBAR)

E-ISSN: 2614-1280 P-ISSN 2622-4771

https://jurnal.stie-aas.ac.id/index.php/IJEBAR

\section{Data Analysis Technique}

Data analysis technique is done by collecting data by distributing questionnaires and supported by documentation methods. The data analysis technique used is multiple linear regression analysis techniques. Data analysis uses the SPSS (Statistical Package for the Social Science) program for windows version 24.0 with the following steps:

\section{a. Data Quality Test}

\section{Test the Validity of the Instrument}

This test provides a true value of a problem to be studied. Testing the validity of each question using analysis per item, which is to tolerate or connect the score of each item with a total score which is the total score of each item (Sugiyono 2010). Questionnaire is said to be valid if $r$ count $>r$ table.

\section{Reliability Test}

Reliability can indicate the extent to which a measuring tool that is reliable or reliable. The way to find out the level of reliability of an instrument is done by testing the data related variables. A variable can be said to be reliable if it can give a Cronbach Alpha value> 0.07 (Nunnally in Imam Ghozali 2012).

\section{b. Classic assumption test}

\section{Test Normality}

Normality is a distribution that can show a balanced distribution of data, most of which are in the middle value. In principle, normality can be detected by looking at the spread of data (points). On the diagonal axis of the graph or by looking at the histogram of the residuals (Imam Ghozali 2012).

\section{Multicollinearity Test}

Multicollinearity Test is a test to find out whether there is significant correlation between independent variables in the multiple linear regression model. To detect the presence or absence of Multicollinearity in the regression model VIF and Tolerance can be used. The cutoff value commonly used to indicate Multicollinearity is a Tolerance value $\leq 0.10$ or equal to VIF $\geq 10$ (Imam Ghozali 2012)

Heteroskedacity Test

The Heteroscedasticity Test is used for the presence or absence of a classic hereroscedasticity assumption that is the variance and residual inequality for all observations in the regression model. A good regression model is Homoscedasticity or heterocedasticity does not occur (Imam Ghozali 2012).

Autocorrelation Test

The autocorrelation test aims to test whether the linear regression model has a correlation between the error of the intruder in period $t$ and the error of $t-1$ (previous) (Imam Ghozali 2012). To detect the presence or absence of autocorrelation researchers used the Durbin Watson test.

\section{c. Multiple Linear Analysis}

The regression equation can be formulated as follows ( Sugiyono 2010 ):

$\mathbf{Y}=\mathbf{a}+\mathbf{b} 1 \mathbf{X} 1+\mathbf{b} 2 \mathbf{X} 2$

Where:

$\mathrm{Y}=$ Intention of turn over

$\mathrm{a}=$ constant

b1, b2 = Regression coefficient 
International Journal of Economics, Business and Accounting Research (IJEBAR)

Peer Reviewed - International Journal

Vol-, Issue-, 2020 (IJEBAR)

E-ISSN: 2614-1280 P-ISSN 2622-4771

https://jurnal.stie-aas.ac.id/index.php/IJEBAR

$\mathrm{X} 1=$ Organizational climate

$\mathrm{X} 2$ = Organizational culture

\section{d. Hypothesis Test}

Coefficient of Determination (R2)

The coefficient of determination (R2) essentially measures how far the model's ability to explain the variation of the dependent variable (Mudrajad Kuncoro 2007)

Partial Significance Test ( $t$-test)

Basically the $t$ test shows how far the influence of one explanatory variable individually in explaining the variation of explanatory variables individually in explaining the variation of the dependent variable (Mudrajad Kuncoro 2007)

Simultaneous Significance Test (F-test)

Basically the $F$ test shows whether all independent variables entered in the model have a joint influence on the dependent variable (Mudrajad Kuncoro 2007.

\section{Research Result}

From the research conducted on one of the state-owned banks in Jakarta, the following results were obtained

\section{Research Data Description}

Research entitled organizational climate organizational culture Through the intention of turnover in one of the Jakarta BUMN bank cabnag using two independent variables and one dependent variable. The two independent variables are organizational climate and organizational culture. One dependent variable is the intention of turn over. Based on the results of the distribution of questionnaires to respondents can be seen the following results:

Turnover Intention Variable Data $(Y)$

The results of data from research respondents in one of the branches of state-owned banks in Jakarta as follows range 18, minimum value of 8 , maximum value of 26 , mean value of 21.1154 with a median of 22.00 and Mode 22. Standard deviations from the data is 3,287 Variance of 10.805, (table 11.).

\begin{tabular}{|c|c|c|}
\hline \multicolumn{3}{|c|}{ Statistics } \\
\hline \multicolumn{3}{|c|}{ INTENSI TURNOVER } \\
\hline \multirow{2}{*}{$\mathrm{N}$} & Valid & 78 \\
\hline & Missing & 0 \\
\hline Mean & & 21.1154 \\
\hline Std. Error of Me & & .37219 \\
\hline Median & & 22.0000 \\
\hline Mode & & 22.00 \\
\hline Std. Deviation & & 3.28705 \\
\hline Variance & & 10.805 \\
\hline Range & & 18.00 \\
\hline Minimum & & 8.00 \\
\hline Maximum & & 26.00 \\
\hline Sum & & 1647.00 \\
\hline
\end{tabular}

Organizational Climate Variable Data (X1)

The results of the data from the research respondents in one branch of a state-owned bank Jakarta are as follows: range 11 , minimum value 33 , maximum value 44 , average value (Mean) of 
International Journal of Economics, Business and Accounting Research (IJEBAR)

Peer Reviewed - International Journal

Vol-, Issue-, 2020 (IJEBAR)

E-ISSN: 2614-1280 P-ISSN 2622-4771

https://jurnal.stie-aas.ac.id/index.php/IJEBAR

37.3590 with a median of 37,000 and mode 37 . The standard deviation of the data is 2.296 , the variance is 5.275 , (table 1.2)

Table 1.2 Descriptive Organizational Climate Variables

\begin{tabular}{|c|c|c|}
\hline \multirow{2}{*}{\multicolumn{3}{|c|}{$\begin{array}{l}\text { Statistics } \\
\text { IKLIM ORGANISASI } \\
\end{array}$}} \\
\hline & & \\
\hline \multirow{2}{*}{$\mathrm{N}$} & Valid & 78 \\
\hline & Missing & 0 \\
\hline \multicolumn{2}{|c|}{ Mean } & 37.3590 \\
\hline \multicolumn{2}{|c|}{ Std. Error of Mean } & .25998 \\
\hline \multicolumn{2}{|c|}{ Median } & 37.0000 \\
\hline \multicolumn{2}{|c|}{ Mode } & 37.00 \\
\hline \multicolumn{2}{|c|}{ Std. Deviation } & 2.29610 \\
\hline \multicolumn{2}{|c|}{ Variance } & 5.272 \\
\hline \multicolumn{2}{|c|}{ Range } & 11.00 \\
\hline \multicolumn{2}{|c|}{ Minimum } & 33.00 \\
\hline \multicolumn{2}{|c|}{ Maximum } & 44.00 \\
\hline \multicolumn{2}{|c|}{ Sum } & 2914.00 \\
\hline
\end{tabular}

Organizational Commitment Variable Data (X2)

The results of data from research respondents in one branch of the state-owned bank of Jakarta are as follows: range 12, minimum value 37, maximum value 49, Mean value of 43.28 with Median 43.00 and Mode 43. Standard deviation from data the number is 2.604, the variance is 6.779 (table 1.3)

Table 1.3 Description of Organizational commitment variables

\begin{tabular}{|c|c|c|}
\hline \multicolumn{3}{|c|}{\begin{tabular}{|l|} 
Statistics \\
KOMITMEN ORGANISASI \\
\end{tabular}} \\
\hline \multirow{2}{*}{$\mathrm{N}$} & Valid & 78 \\
\hline & Missing & 922 \\
\hline \multicolumn{2}{|l|}{ Mean } & 26.72 \\
\hline \multicolumn{2}{|c|}{ Std. Error of Mean } & .605 \\
\hline \multicolumn{2}{|l|}{ Median } & 26.00 \\
\hline \multicolumn{2}{|l|}{ Mode } & 22 \\
\hline \multicolumn{2}{|l|}{ Std. Deviation } & 5.347 \\
\hline \multicolumn{2}{|l|}{ Variance } & 28.595 \\
\hline \multicolumn{2}{|l|}{ Range } & 28 \\
\hline \multicolumn{2}{|l|}{ Minimum } & 14 \\
\hline \multicolumn{2}{|l|}{ Maximum } & 42 \\
\hline \multicolumn{2}{|l|}{ Sum } & 2084 \\
\hline
\end{tabular}

\section{Test Requirements Analysis}

Before the data is analyzed, there are several assumptions that must be fulfilled to be able to be forwarded in hypothesis testing. Test requirements in this analysis are as follows:

Normality Test

The normal test method for data distribution is done by looking at the shape of the histogram graph, if the graph forms a bell or mountain then the distribution is normal. 
International Journal of Economics, Business and Accounting Research (IJEBAR)

Peer Reviewed - International Journal

Vol-, Issue-, 2020 (IJEBAR)

E-ISSN: 2614-1280 P-ISSN 2622-4771

https://jurnal.stie-aas.ac.id/index.php/IJEBAR

While the Kolmogorov Smirnov normality test concept method is to compare the data distribution (which will be tested for normality) with the standard normal distribution. Standard normal distribution is data that has been transformed into Z-Score and assumed to be normal.

So actually the Kolmogorov Smirnov test is to see whether the residual value is normally distributed or not. A good regression model is to have a normally distributed residual value. So the normality test is not carried out on each variable but on the residual value.

Hypothesis:

H0: Population is normally distributed

H1: Population not normally distributed

Basic decision making:

If the probability (sig value) $>0.05$ then $\mathrm{H} 0$ is accepted.

If the probability (sig value) $<0.05$ then $\mathrm{H} 0$ is rejected.

Figure 2.2 Turnover Intention Variable Histogram Diagram

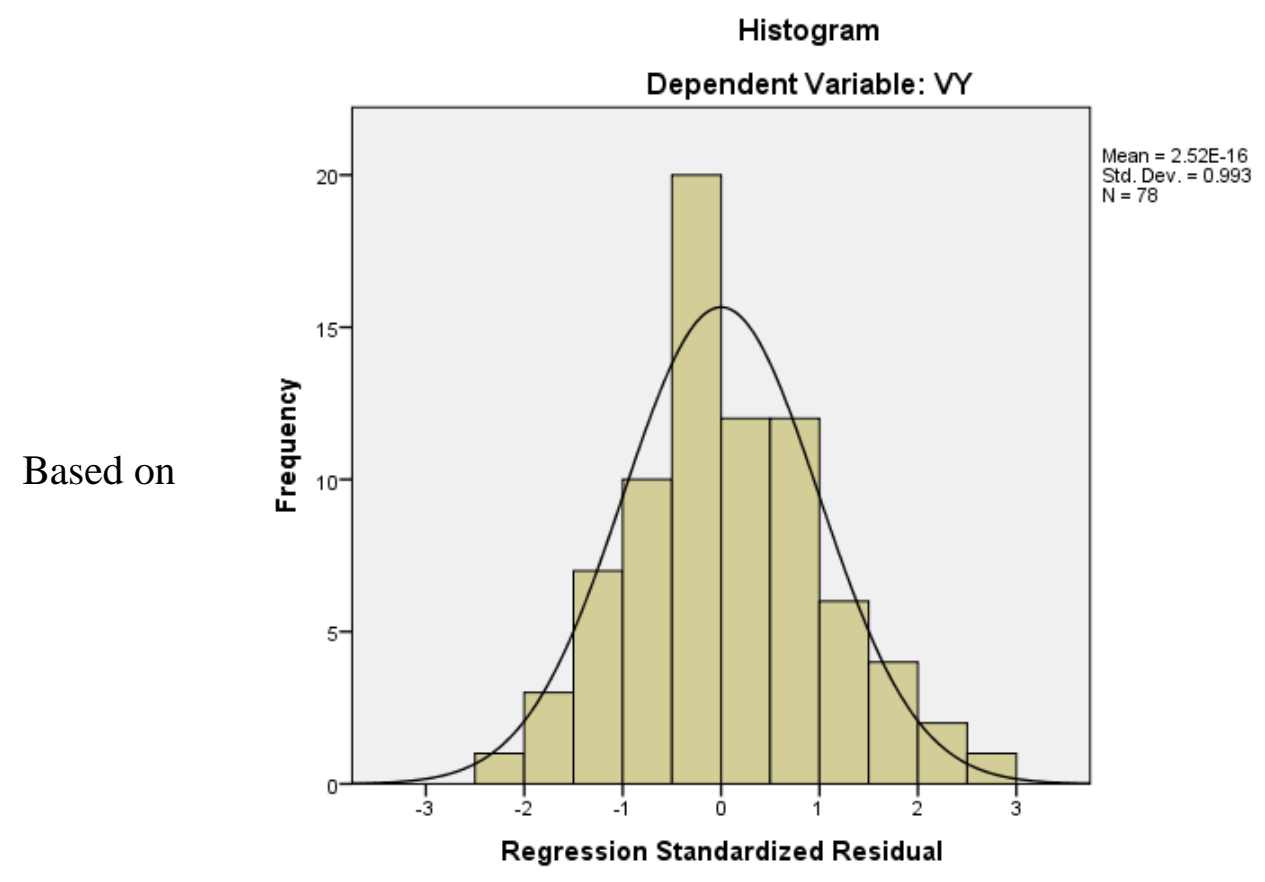

Figure 2.2 Histogram diagram can be seen that the graph forms a mountain or a bell. With this, residual data is normally distributed.

Whereas based on the Normal P-Plot distribution chart is described as follows 
International Journal of Economics, Business and Accounting Research (IJEBAR)

Peer Reviewed - International Journal

Vol-, Issue-, 2020 (IJEBAR)

Normal P-P Plot of Regression Standardized Residual

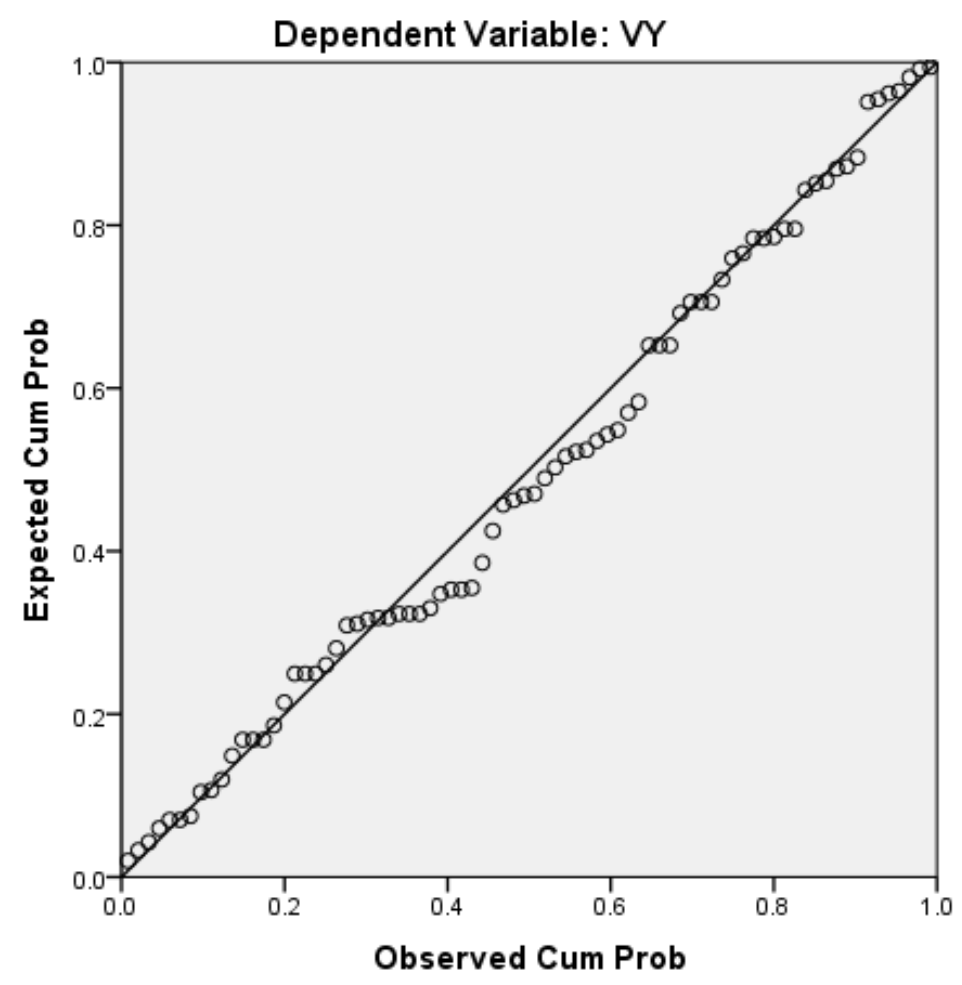

Based on the P-Plot graph it can be concluded that the points spread around the diagonal line and the distribution follows the direction of the diagonal line, and it can be concluded that the residuals are distributed with the assumption of normality.

Table 1.4. Kolmogorov Smirnov Test Results

\begin{tabular}{|c|l|c|}
\hline \multicolumn{2}{|c|}{ One-Sample Kolmogorov-Smirnov Test } \\
\hline \multicolumn{2}{|c|}{$\mathrm{N}$} & $\begin{array}{c}\text { Unstandardized } \\
\text { Residual }\end{array}$ \\
\hline \multirow{2}{*}{ Normal Parameters ${ }^{\mathrm{a}, \mathrm{b}}$} & Mean & 78 \\
\cline { 2 - 3 } & Std. Deviation & .0000000 \\
\hline \multirow{3}{*}{ Most Extreme Differences } & Absolute & .126 \\
\cline { 2 - 3 } & Positive & .089 \\
\cline { 2 - 3 } & Negative & -.126 \\
\hline \multicolumn{2}{|c|}{ Test Statistic } & .126 \\
\hline Asymp. Sig. (2-tailed) & $.004^{\mathrm{C}}$ \\
\hline
\end{tabular}

\section{Uji Linieritas}

This test is used as a prerequisite in correlation analysis or linear regression. Tests on SPSS 24 , using Test for Linearity with a significance level of "0.05". Two variables are said to have a linear relationship if the significance (Linearity) $<0.05$.

Tabel 1.5 Hasil Uji Linieritas $\mathrm{X}_{1}$ dan $\mathrm{X}_{3}$

\begin{tabular}{|c|c|c|c|c|c|c|c|}
\hline \multicolumn{9}{|c|}{ ANOVA Table } \\
\hline \multicolumn{2}{|c|}{} & $\begin{array}{c}\text { Sum of } \\
\text { Squares }\end{array}$ & Df & Mean Square & F & Sig. \\
\hline $\begin{array}{c}\text { INTENSI } \\
\text { TURNOVER * } \\
\begin{array}{c}\text { IKLIM } \\
\text { ORGANISASI }\end{array}\end{array}$ & $\begin{array}{c}\text { Between } \\
\text { Groups }\end{array}$ & (Combined) & 370.421 & 18 & 20.579 & 2.631 & .003 \\
\cline { 2 - 8 }$y$ & Linearity & 156.782 & 1 & 156.782 & 20.042 & .000 \\
\cline { 2 - 9 } & Deviation from Linearity & 213.640 & 17 & 12.567 & 1.606 & .092 \\
\hline
\end{tabular}


International Journal of Economics, Business and Accounting Research (IJEBAR)

Peer Reviewed - International Journal

Vol-, Issue-, 2020 (IJEBAR)

E-ISSN: 2614-1280 P-ISSN 2622-4771

https://jurnal.stie-aas.ac.id/index.php/IJEBAR

\begin{tabular}{|l|l|l|l|l|l|l|}
\hline & Within Groups & 461.540 & 59 & 7.823 & & \\
\cline { 2 - 7 } & Total & 831.962 & 77 & & & \\
\hline
\end{tabular}

The

table

above shows the linearity test results known to the value of Sig.deviation from linearity of $0.092>0.05$, it can be concluded that there is a linear relationship between the dependent variable and the independent variable.

Tabel 1.6 Hasil Uji Linieritas $\mathbf{X}_{2}$ dan $\mathbf{X}_{3}$

\begin{tabular}{|c|c|c|c|c|c|c|c|}
\hline \multicolumn{8}{|c|}{ ANOVA Table } \\
\hline & & & $\begin{array}{l}\text { Sum of } \\
\text { Squares }\end{array}$ & Df & Mean Square & $\mathbf{F}$ & Sig. \\
\hline \multirow{5}{*}{$\begin{array}{l}\text { INTENSI } \\
\text { TURNOVER * } \\
\text { KOMITMEN } \\
\text { ORGANISASI }\end{array}$} & \multirow{3}{*}{$\begin{array}{c}\text { Between } \\
\text { Groups }\end{array}$} & (Combined) & 94.788 & 11 & 8.617 & .772 & .004 \\
\hline & & Linearity & 33.854 & 1 & 33.854 & 3.031 & .002 \\
\hline & & Deviation from Linearity & 60.934 & 10 & 6.093 & .546 & .073 \\
\hline & \multicolumn{2}{|c|}{ Within Groups } & 737.173 & 66 & 11.169 & & \\
\hline & \multicolumn{2}{|l|}{ Total } & 831.962 & 77 & & & \\
\hline
\end{tabular}

The

table above shows the linearity test results known to the value of Sig. Deviation from linearity of $0.851>0.05$, it can be concluded that there is a linear relationship between the dependent variable and the independent variable.

\section{Multicollinearity Test}

Multicollinearity test aims to test whether the regression model found a correlation between independent variables. If the independent variables are correlated with each other, then these variables are not orthogonal. Orthogonal variables are independent variables where the value of correlation between fellow independent variables is equal to zero. Multicollinearity is a condition where there is a linear relationship or high correlation between each independent variable in the regression model. Multicollinearity usually occurs when most of the variables used are interrelated in a regression model.

Table 1.7 Multicollinearity Test

\begin{tabular}{|c|c|c|c|c|}
\hline & Variabel & Tolerance & VIF & Keterangan \\
\hline & Organizatonal climate & 1,000 & 1,000 & $\begin{array}{c}\text { Bebas } \\
\text { Multikolinieritas }\end{array}$ \\
\hline & Organisasi commitment & 1,000 & 1,000 & $\begin{array}{c}\text { Bebas } \\
\text { Multikolinieritas }\end{array}$ \\
\hline
\end{tabular}

The table above shows that the results of multicollinearity test are explained, that the results of tolerance value 1,000 concluded that value $>0.10$, then it was decided that there was no multicollinearity and the results of VIF 1,000 were concluded $<10.00$ then it was decided that there was no multicollinearity.

\section{Autocorrelation Test}

A good regression equation does not have an autocorrelation problem. If autocorrelation occurs, the equation will not be good or predictable. Size in determining whether or not there is an autocorrelation problem with the Durbin-Watson (DW) test, with the following 
International Journal of Economics, Business and Accounting Research (IJEBAR)

Peer Reviewed - International Journal

Vol-, Issue-, 2020 (IJEBAR)

E-ISSN: 2614-1280 P-ISSN 2622-4771

https://jurnal.stie-aas.ac.id/index.php/IJEBAR

conditions: A positive autocorrelation occurs if DW is below -2 (DW <-2). And no autocorrelation if DW is between -2 and +2 or $-2<\mathrm{DW}+2$

\section{Hypothesis Testing}

1. Multiple Linear Regression Analysis

Based on data from the spss 24 program, we can get the results that we can see in the following table:

Table 1.8 Test Results of Multiple Linear Regression Analysis

\begin{tabular}{|c|c|c|c|c|c|}
\hline \multirow{2}{*}{ Model } & \multicolumn{2}{|c|}{$\begin{array}{l}\text { Unstandardized } \\
\text { Coefficients }\end{array}$} & $\begin{array}{c}\text { Standardized } \\
\text { Coefficients }\end{array}$ & \multirow[t]{2}{*}{$\mathrm{t}$} & \multirow[t]{2}{*}{ Sig. } \\
\hline & & Std. Error & Beta & & \\
\hline (Constant) & 23.644 & 5.816 & & 4.065 & .000 \\
\hline IKLIM ORGANISASI & -.254 & .146 & -.177 & -1.737 & .046 \\
\hline $\begin{array}{l}\text { KOMITMEN } \\
\text { ORGANISASI }\end{array}$ & -.261 & .063 & -.424 & -4.150 & .000 \\
\hline \multicolumn{6}{|c|}{ a. Dependent Variable: ITENSI TURNOVER } \\
\hline
\end{tabular}

Tabel 1.8 Hasil Uji F

\begin{tabular}{|l|l|c|c|c|c|c|}
\hline Model & Sum of Squares & df & Mean Square & F & Sig. \\
\hline \multirow{5}{*}{} & Regression & 182.897 & 2 & 91.448 & 10.567 & $.000^{\mathrm{b}}$ \\
\cline { 2 - 7 } & Residual & 649.065 & 75 & 8.654 & & \\
\cline { 2 - 7 } & Total & 831.962 & 77 & & & \\
\hline
\end{tabular}

Tabel 1.9 Hasil Uji Koefisien

\begin{tabular}{|c|c|c|c|c|}
\hline Model & $\mathbf{R}$ & $\mathbf{R}$ Square & $\begin{array}{c}\text { Adjusted R } \\
\text { Square }\end{array}$ & $\begin{array}{c}\text { Std. Error of the } \\
\text { Estimate }\end{array}$ \\
\hline & $.469^{\mathrm{a}}$ & .220 & .199 & 2.94180 \\
\hline $\begin{array}{l}\text { a. Predictors: (Constant), KOMITMEN ORGANISASI, IKLIM } \\
\text { ORGANISASI }\end{array}$ \\
\hline
\end{tabular}

Based on the table above, the Multiple Linear Regression Analysis Test Results are as follows: $\mathrm{Y}=23,644-0,177 \mathrm{X} 1-0,424 \mathrm{X} 2$

a. Regression coefficient of organizational climate variable $(X 1)=-0,177$

Organizational climate variables have an inverse effect on the turnover intention of permanent employees. The more conducive an organizational environment will have an impact with the intention of permanent employee turnover which is getting lower, so the more non-conducive an organizational climate will have an impact with the high intention of permanent employee turnover.

b. Regression coefficient of organizational commitment variable $(X 2)=-0,424$

The variable of organizational commitment has an inverse effect with the intention of permanent employee turnover. The higher organizational commitment will have an impact with the low intention of permanent employee turnover, similarly the lower organizational commitment will have an impact with the high intention of permanent employee turnover.

\section{Hypothesis 1 Testing (Test F)}

Based on the ditas table, it can be seen that the calculation result obtained an F count of 10,567 with a significance level of 0,000 , of course less than $\alpha(0,000<0.05)$. The results of the table show that the coefficient of determination $(\mathrm{R})$ is 0.469 which means that the influence of 
International Journal of Economics, Business and Accounting Research (IJEBAR)

Peer Reviewed - International Journal

Vol-, Issue-, 2020 (IJEBAR)

E-ISSN: 2614-1280 P-ISSN 2622-4771

https://jurnal.stie-aas.ac.id/index.php/IJEBAR

organizational climate variables and organizational commitment to turnover intentions is $46.9 \%$ while the remaining $53.1 \%$ is influenced by other variables outside this study

So it was concluded that the first hypothesis was decided the organizational climate and organizational commitment together had a significant effect on turnover intentions on permanent employees one of PT. Bank BUMN Jkarta.

Hypothesis Testing 2. (T Test)

Based on the table above, it can be seen that the calculation results are obtained as follows:

a. Organizational Climate Variable (X1) has a t-count of -1737 with a significance level of 0.046 less than $\alpha(0.046<0.05)$. So the conclusion is that organizational climate has a significant negative effect on the intention of permanent employee turnover.

b. The variable organizational commitment (X2) has a tcount of - 4,150 with a significance level of 0,000 less than $\alpha(0,000<0.05)$. So the conclusion is that organizational commitment has a significant negative effect on the intention of permanent employee turnover.

The second hypothesis which states organizational climate and organizational commitment partially has a significant effect on employee turnover intentions in one of the Jakarta StateOwned Banks

\section{Interpretation of Hypothesis Testing}

Next is to interpret the hypothesis testing for all variables, namely the correlation of $\mathrm{X} 1, \mathrm{X} 2$ and Y. Based on the equation of the double linear regression line, obtained Y $=23,644-0,177 \mathrm{X} 1-0$, $424 \mathrm{X} 2$ The value of $\mathrm{Y}$ will increase or decrease depending on the positive coefficients X1 and $\mathrm{X} 2$ or negative. When viewed from the multiple linear regression equation, then if the Archival Training (X1) and computer (X 2) have increased it will affect the effectiveness of work (Y), because the regression equation shows a positive direction. The changes that occur in the value of $\mathrm{Y}$ are in line with changes in the variables $\mathrm{X} 1$ and $\mathrm{X} 2$.

\section{Conclusion}

- Organizational Climate has a significant negative effect on employee turnover intentions in one of the BUMN Banks. This matter. Based on the results of research hypotheses in the $t$ test the Standardized Coefficients Beta value was presented with a negative value of -0.177 and $t$-test results of -1.737 , which means $t$ arithmetic less than $t$ table $(-1.737$ $<1.995)$. The amount of sig. of 0.046 less than the significance level of $5 \%(0.05)$ ie $0.046<0.05$ so it can be concluded that $\mathrm{H} 0$ is rejected and $\mathrm{H} 1$ is accepted, meaning there is a significant negative effect of $\mathrm{X} 1$ on $\mathrm{Y}$.

- Organizational Commitment has a significant negative effect on turnover intentions on employees of one of the BUMN Banks This is based on the results of the hypothesis in the $t$ test presented the standardized Coefficients Beta value with a negative value of 0.424 and the test result of -4.150 , which means $t$ count is less than t table $(-4,150$ $<1,995)$. The amount of sig. equal to 0,000 less than the significance level of $5 \%(0.05)$ ie $0.046<0.05$ so it can be concluded that $\mathrm{H} 0$ is rejected and $\mathrm{H} 1$ is accepted, meaning there is a significant negative effect of $\mathrm{X} 2$ on $\mathrm{Y}$.

- Anova results obtained f count of 10.567 with a value of $f$ table significance level of 5\% of 3.117. The magnitude of the calculated $\mathrm{f}$ value is greater than $\mathrm{f}$ table that is $10,567>$ 3.117 and for a significance value of 0,000 less than 0.05 namely $(0,000<0.05)$ So it can be concluded that the organizational climate and organizational commitment together 
International Journal of Economics, Business and Accounting Research (IJEBAR)

Peer Reviewed - International Journal

Vol-, Issue-, 2020 (IJEBAR)

E-ISSN: 2614-1280 P-ISSN 2622-4771

https://jurnal.stie-aas.ac.id/index.php/IJEBAR

have a significant negative effect on intention employee turnover of one of Jakarta's state-owned banks

\section{References}

Akdon. (2007). Strategic Management for Education Management. Bandung: Alfabeta.

Armstrong, M. (2009). Armstrong's Handbook Of Human Resource Management Practice (11th editi). London and Philadelphia: Kogan Page.

Colquitt, J. A., Lepine, J. A., \& Wesson, M. J. (2009). Organizational Behavior: Improving Performance and Commitment in the Workplace. New York: Mc.Graw-Hill.

Dubrin, A. J. (2002). Fundamentals of Organizational Behavior. USA: South Western Thomson Learning.

Gibson, J. L., Ivancevich, J. M., Donnelly, J. H., \& Konopski, R. (2006). Organizations: Behavior Structure Proceses (Internatio). New York: McGraw-Hill Companies.

Greenberg, J., \& Baron, R. A. (2003). Behavior In Organization. New Jersey: Prentice Hall, Pearson Education, Inc.

Lussier, R. N. (2008). Human Relations in Organizational Applicattion and Skills Building, (7th editio). New York: McGraw-Hill.

Luthans, F. (2008). Organizational Behavior (Internatio). New York: McGraw-Hill Companies.

Mcshane, S. L., \& Von Glinow, M. A. (2008). Organizational Behavior (Internatio). New York: McGraw-Hill Companies.

Meyer, J., \& Hercsovitch, L. (2001). Commitment in the workplace: Toward a general model, Human resource management review. Human Resource Management Review, 317.

Mullins, L. J. (2006). ESSENTIALS OF ORGANISATIONAL BEHAVIOUR. England: Pearson Education Limited.

Natalie, A. J., \& John, M. P. (2011). The measurement and antecedents of affective, continuance and normative commitment to the organization. Journal of Occupational Psychology, Vol. $63,1-18$.

Nelson, D. L., \& Quick, J. C. (2006). Organizational Behavior: Foundations, Realities \& Challenges. Thomson South Western.

Newstrom, J. W. (2007). Organizational Behavior: Human Behavior at Work. New York: Mc Graw-hill.

Owens, R. G. (1995). Organizational behavior in education (5th editio). USA: Boston Allyn and Bacon.

Plunkett, W. R., Attner, R. F., \& Allen, G. S. (2008). Management: Meeting and Exceeding Customer Expectation (9th editio). USA: Thomson Corporation.

Robbins, S. P., \& Judge, T. A. (2009). Organizational Behavior. New York: Pearson Prentice Hall.

Robbins, S. P., \& Judge, T. A. (2013). Organizational Behavior (15th editi). https://doi.org/10.1007/BF01148546

Stiffler, M. A. (2006). Performance (Creating the performance-Driven Organization). New Jersey: John Wiley \& Sons. 